\title{
Development of green shipping network to enhance environmental and economic performance
}

\author{
Y.H. Venus Lun, DBA, Assistant Professor \\ The Hong Kong Polytechnic University, Hong Kong
}

\begin{abstract}
To secure cargoes, containerships operate double or triple calling of ports in the Pearl River Delta (PRD) region in China. Such shipping operations generate high $\mathrm{CO}_{2}$ emissions. This paper suggest a green shipping network (GSN) as a useful tool to transship containers from feeder ports to hub ports to lower the overall $\mathrm{CO}_{2}$ emissions in the region. From the perspective of scale operations from using the hub-and-spoke approach and the deployment of mega ships, developing a GSN within the PRD region can be beneficial, both economically and environmentally, to port users in the container transport chain.
\end{abstract}

Keywords: Shipping Management; Shipping Network; Environmental Management; Firm Performance

\section{INTRODUCTION}

The costs of environmental protection for firms to reduce $\mathrm{CO}_{2}$ emission have increased considerably since the 1970 s. These environmental costs are expected to rise even further. In the context of shipping operations, initiatives to reduce $\mathrm{CO}_{2}$ emission include: (1) use shore power, (2) reduce vessel speed, and (3) use cleaner fuel. Extra operational costs are incurred for upgrading equipment to use shore power, modifying operational procedures to cope with reduced vessel speed, and complying with environmental regulations. To remain competitive, costeffective green shipping operations are essential for shipping firms (Lun et al, 2010). Hence, research on environmental management has extended from the focus on pollution control to the emphasis on both economic and environmental performance. Integrating both environmental concerns and commercial operations into shipping management has become increasingly important for shipping firms (Lun, 2011).

To enjoy scale operations, green shipping networks (GSN) can be established by using a hub-and-spoke system to support large containerships running forth and back between major ports (Lun and Browne, 2009). Such a system requires delivery of containers to feeder port first by trucks, then transferred to hub port by barges. In intermodal transport operations, the accessibility of road transport is the highest among all transport modes. However, the level of $\mathrm{CO}_{2}$ emission for trucking is the highest. Hence, containers should be first truck to the nearest port to minimize environmental damage. From the perspective of container port operations, ports in the region can be classified into feeder ports, hub ports, and direct ports. Under the huband-spoke system, feeder ports receive domestic containers and transport them to hub ports. Hub ports are ports of loading that handle containers from feeder ports and also their direct containers. Benefits of the development of GSN include: (1) removing of mega containership vessels multiple callings port in a region, and (2) lowering $\mathrm{CO}_{2}$ emissions by using barge delivery between feeder ports and hub ports.

In view of the global community's increasing concern for the environment, there is an urgent need for the PRD region to enhance environmental performance through the development of a GSN. However, establishing a GSN requires the full support of the port users, which in turn needs to adopt green shipping practices (GSPs) for the sustainable development of the shipping related industries. Users in the port community include shipping companies, shippers, terminal operators, and other transport operators (Lun and Caiou 2009). The establishment of a GSN is important to all port users. According to Lun et al. (2011), users in the port community can be characterized into the following types: (1) first-party users are parties that physically own the cargo to transport, e.g., global traders and small domestic exporters, (2) second-party users are parties that own the vehicles and/or facilities to provide logistics and transport services, (3) third-party users are parties that directly offer services to shippers, e.g., freight forwarders, customs brokers, and other value-added service providers, (4) fourth-party users are parties that supervise third-party logistics services providers to provide services to meet customer requirements, and (5) fifth-party users are parties that conduct research studies or provide consultation services to facilitate the development and growth of the region.

Port operations are closed linked with environmental quality (Gallagher, 2009). The challenge of today's shipping 
industry is to enhance economic performing while reducing negative environmental impacts. Environmentally sustainable operations have emerged as an important topic for firms to prosper and for policy makers to showcase their commitment to environmentally friendly operations (Sarkis et al., 2010). For the past few decades, the emissions of greenhouse gases have increased by approximately $70 \%$ (Metz et al., 2007). Increasing emissions of greenhouse gases due to transportation related activities have become a serious concern. There is an urge for shipping firms to adopt green shipping practices (GSPs) to reduce the environmental damage caused by global trade activities (Lai et al., 2011). Establishing a GSN in the PRD region can also balance the interests between reducing $\mathrm{CO}_{2}$ emissions and running market-led operations for economic gains. To establish a GSN, it is essential to investigate green shipping practices (GSPs) as organizational antecedents, and to achieve the ultimate goal of developing green shipping hubs (GSHs). This study is important to users in the shipping related industries in two perspectives. The first one concerns the identification of a potential GSN and the development of GSHs in the PRD region. The second one is to advance knowledge in shipping research that GSPs are important to the establishment of GSN.

\section{DEVELOPMENT OF GREEN SHIPPING NETWORK}

Liner shipping provides a regular publicized schedule of shipping service between seaports. a function of liner shipping is to satisfy the shipping demand for regular freight transport. Liner ships service international seaborne trade with cargoes consolidated from a large number of consignments from different shippers. a key objective of liner shipping operations is to fully utilize the capacity of their fleets. Operating a large container ship involves huge capital investment and high daily operating costs (Lun and Marlow, 2011). Shipping firms can gain efficiency from improving fleet utilization through ship routing, which is concerned with the assignment of sequences of ports to be visited by ships (Zhang et al., 2011).
The factors needed to be considered by shipping firms to plan liner shipping services include shipping service scope and fleet mix (Lun and Browne, 2009). In planning a liner service route, it is important to decide the type of shipping routes. With increasing significance of pendulum services and transshipment networks, most liner services on the main shipping routes provide the line-bundling service. By the overlay of their roundtrips, shipping firms can offer a desired calling frequency to customers. For instance, OOCL, one of the mega global shipping lines, offers four weekly sailing line-bundling shipping services from South China to North America with its alliance members. The ports of call of these four liner shipping services are illustrated in Table 1. Other global liner shipping companies offer similar line bundling loops to transport containers to and from the PRD region.

Asia is one of the busiest areas for containerized trade. The top container ports of the world in terms of throughput are Shanghai, Singapore, Hong Kong and Shenzhen. Two of these top container ports, namely Hong Kong and Shenzhen, belong to the PRD region and they are adjacently located and economically connected. However, unproductive competition seems to emerge due to unclear roles of individual ports and a serious lack of development of a shipping network among PRD ports. Facing with the environmental concern, it is essential to use all resources efficiently and effectively. From the perspective of shipping operations, use of equipment in the containers terminals and shipping capacity should be used effectively to reduce wastes. Doubling of triple calling of ports involve longer voyage distance which can be considered as a waste of resources.

In addition to using extra shipping capacity, calling more ports in the region leads to extra $\mathrm{CO}_{2}$ emissions. As shown in Table 1, all the four liner services (i.e., SSX, PNX, PAX, and SCE) call both the ports of Hong Kong and Shenzhen, which incur addition voyages distance in the PRD region. The resultant extra $\mathrm{CO}_{2}$ emissions can be avoided if a GSN can be developed to reduce the environmental harms associated with shipping routes. As shown in Table 1, it is estimated that an excessive 8.1 million $\mathrm{kg}$ of $\mathrm{CO}_{2}$ is emitted annually because of

Tab. 1. OOCL Liner Shipping Service (South China Outbound to North America)

\begin{tabular}{|c|c|c|c|c|}
\hline $\begin{array}{l}\text { Weekly Sailing } \\
\text { Liner Service }\end{array}$ & Ship Size & $\begin{array}{c}\text { Ports of call in PRD } \\
\text { region }\end{array}$ & $\begin{array}{c}\text { Voyage distance between } \\
\text { ports in PRD }\end{array}$ & $\begin{array}{c}\mathrm{CO} 2 \text { emission in PRD } \\
\text { region }\end{array}$ \\
\hline \multirow{2}{*}{$\begin{array}{l}\text { Super Shuttle } \\
\text { Express } \\
\text { (SSX) }\end{array}$} & \multirow{2}{*}{$8,000 \mathrm{TEU}$} & \multirow{2}{*}{$\begin{aligned} \mathrm{SE}^{\mathrm{a})} \rightarrow & \mathrm{SW}^{\mathrm{b})} \rightarrow \mathrm{HK}^{\mathrm{c})} \text { to } \\
& \text { America }\end{aligned}$} & $\mathrm{SE} \rightarrow \mathrm{SW}=115 \mathrm{~km}$ & \multirow{2}{*}{$\begin{array}{c}(115+45) \times(8000 \times \\
\left.75 \%)^{\mathrm{d})} \times 86^{\mathrm{e}}\right)= \\
=85,560,000 \text { grams }\end{array}$} \\
\hline & & & $\mathrm{SW} \rightarrow \mathrm{HK}=45 \mathrm{~km}$ & \\
\hline $\begin{array}{l}\text { Pacific-North- } \\
\text { West Express } \\
\text { (PNX) }\end{array}$ & 7,500 TEU & $\mathrm{SW} \rightarrow \mathrm{HK}$ to America & $\mathrm{SW} \rightarrow \mathrm{HK}=45 \mathrm{~km}$ & $\begin{array}{c}45 \times(7500 \times 75 \%) \times 86= \\
\quad=21,768,750 \text { grams }\end{array}$ \\
\hline \multirow{2}{*}{$\begin{array}{l}\text { Pacific Atlantic } \\
\text { Express } \\
\text { (PAX) }\end{array}$} & \multirow[b]{2}{*}{$4,800 \mathrm{TEU}$} & \multirow{2}{*}{ 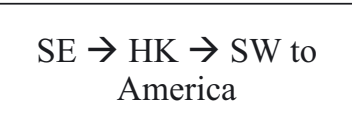 } & $\mathrm{SE} \rightarrow \mathrm{HK}=70 \mathrm{~km}$ & \multirow{2}{*}{$\begin{array}{c}(70+45) \times(4800 \times 75 \%) \times \\
\times 86=35,604,000 \text { grams }\end{array}$} \\
\hline & & & $\mathrm{HK} \rightarrow \mathrm{SW}=45 \mathrm{~km}$ & \\
\hline $\begin{array}{l}\text { South China East } \\
\text { Coast Express } \\
\text { (SCE) }\end{array}$ & 4,500 TEU & $\mathrm{SW} \rightarrow \mathrm{HK}$ to America & $\mathrm{SW} \rightarrow \mathrm{HK}=45 \mathrm{~km}$ & $\begin{array}{l}45 \times(4500 \times 75 \%) \times 86= \\
\quad=13,061,250 \text { grams }\end{array}$ \\
\hline \multicolumn{4}{|c|}{$\mathrm{CO}_{2}$ emissions per week (due to double or triple calls at PRD ports) } & $155,994,000$ grams \\
\hline \multicolumn{4}{|c|}{$\mathrm{CO}_{2}$ emissions per year (due to double or triple calls at PRD ports) } & 8.1 million $\mathrm{kg}$ \\
\hline
\end{tabular}

a) $\mathrm{SE}=$ Shenzhen East

b) $\mathrm{SW}=$ Shenzhen West

c) $\mathrm{HK}=$ Hong Kong

d) Assume $75 \%$ load factor

e) Assume $\mathrm{CO}_{2}$ emission by ocean-going vessel $=86$ grams per $\mathrm{km} / \mathrm{TEU}$ (i.e., twenty-foot equivalent unit) 
double or triple calling of PRD ports. Only one shipping line generates such a huge amount of $\mathrm{CO}_{2}$ emissions. Other shipping lines offering liner services to and from PRD ports also operate similar routing patterns. As a results, there are huge amount of avoidable $\mathrm{CO}_{2}$ emissions resulting from double or even multiple calling of ports within the PRD region.

Liner shipping service providers make key decision in ship routing to secure cargoes. In international shipping, the head hauls are eastbound route from Asia to America and westbound route from Asia to Europe. To development green shipping network, port operators also play an important role. There are several container terminal operators in the PRD region with Hong Kong and Shenzhen as the key operating areas. The port of Hong Kong is served by five operators where HPH and MTL are the main terminal operators. On the other hand, the port of Shenzhen consists of ports in Shenzhen East (i.e., Yantian) and Shenzhen West (i.e., Chiwan, Dachan Bay, and Shekou). In the port of Shenzhen, the port of Shenzhen East is operated by HPH and the ports of Shenzhen West are operated by MTL.

Estimation of the direct voyage distance between the port of loading and the port of discharge can be a useful tool to identify the relative environmental cost for containership transport between these ports. An alternative route to transport containers is to develop a shipping network to transport the containers from a feeder port to a hub port by barges, and then ship the containers to discharging ports by containerships. Reduction of environmental damage in the PRD region is achieved when the alternative route is shorter than the direct route in terms of the equivalent containership distance (ECD) travelled. These shipping routes also avoid double or triple calling of ports in the PRD region. As a result, the shortest route for any given pair of origin and destination originating in this region is the route with the lowest environmental cost for container shipping.

Appendix 1 illustrates the formulas to determine the voyage distances of a direct voyage and alternative routes between the ports in the PRD region and their discharging ports. This formula is a useful tool to identify the routes with the lowest environmental costs when shipping containers take routes via other ports instead of using direct loading. Based on proposed tool, the green shipping network for head hauls in PRD region is shown in Figure 1. Ports in East of Shenzhen (SE) and Hong Kong (HK) should develop as hub ports to handle eastbound (EB) cargo to America while ports in West of Shenzhen (SW) and Hong Kong (HK) should develop as hub ports to handle westbound (WB) cargo to Europe.

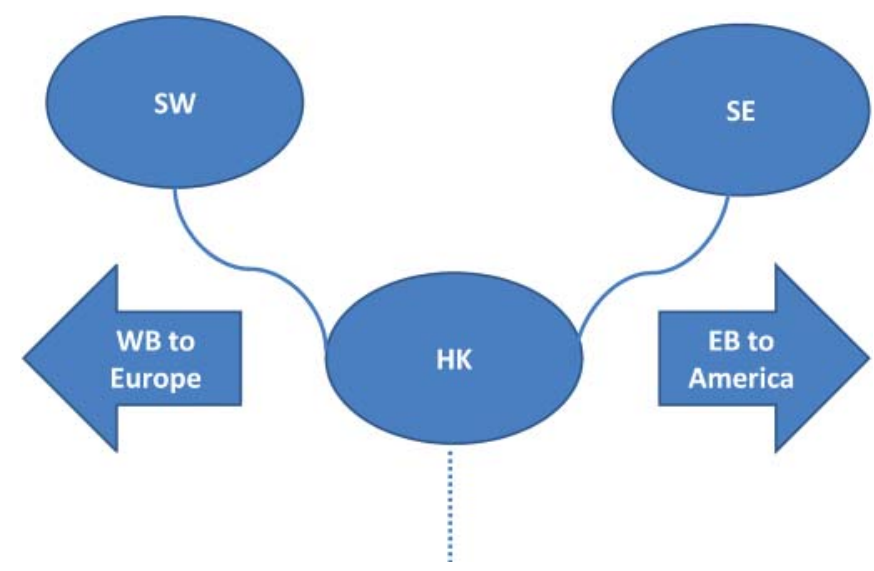

Fig. 1. Proposed Green Shipping Network in PRD

To minimize $\mathrm{CO}_{2}$ emissions, it is desirable to develop a GSN in PRD ports by using barges to carry containers from feeder ports to hub ports, which helps reduce the total emission volume. With the development of such a GSN,
GSHs in the PRD region can be identified. As trucks produce the highest level of $\mathrm{CO}_{2}$ emissions, the use of trucking should be minimized. For inland transport, containers should be transported from the shippers' warehouses to the nearest port within the PRD region to reduce $\mathrm{CO}_{2}$ emissions. Ports can then be classified into feeder ports and hub ports. Feeder ports are ports that have higher external costs when they act as ports of loading for mainland containerships instead of using barges to transport containers to hub ports. Hence, it is worthwhile for feeder ports to transport their containers to a GSH for minimizing the total external cost in the PRD region. Hub ports are ports of loading that handle containers from feeder ports and also their direct containers.

\section{ADOPTION OF GREEN SHIPPING NETWORK}

Using $\mathrm{CO}_{2}$ emissions as the analytical base, ports in the PRD region can be classified as feeder ports or hub ports. To enhance environmental performance, it is desirable to develop GSHs in the PRD region with the objective of having fewer ports of call for larger containerships. The GSN can be operated by large vessels based on scheduling vessels forth and back between major ports and supported by a hub-andspoke system, where containers are first delivered to a feeder (or spoke) port by trucks, followed by transfer to the hub port by barges. Containers can deliver to the hub port directly if the nearest port is a hub port. a shipping hub is generally well equipped to facilitate the quick turnaround time of a large containership. Such a hub allows the development of linkages between origins and destinations where port users in the port community can achieve operational gains from operating cost through the deployment of larger ships and provide wider service through the development of feeder ports. It can also serve as a transshipment place, where feeder shipping routes are connected with one another with trunk routes for ocean-going voyages. Recently, container shipping firms have established connections with hub ports in order to make their operations cost-effective.

The use of shipping hubs implies the deployment of larger ships to transport containers. Container shipping companies operating larger ships can benefit from reduced cost per TEU. Cost efficiency is one of the most popular size-based strategies for container shipping firms to deploy mega ships. The development of a GSN indicates that huge cargo volumes are available in the hub port, which facilitates the deployment of bigger ships. Reasons for container shipping firms to deploy bigger ships include (1) large ships allow the carriage of a greater cargo volume per ship, (2) large ships equipped with efficient engines improve vessel speed, and (3) greater flexibility in container stowage can be achieved with larger ships. Larger ships are also more energy-efficient, requiring less fuel and emitting less $\mathrm{CO}_{2}$ per TEU transported.

A shipping network refers to the framework of routes within a system of nodes. Using the main container ports in the PRD region as nodes, this study proposes routes for transporting containers from these nodes to their destinations as a GSN in the PRD region. a corporate shipping network can be seen as strategic interdependence, i.e., "a situation in which one firm has the tangible or intangible resources or capabilities beneficial to but not possessed by the others" (Lun et al., 2009). With the development of shipping hubs in the PRD region, the shipping industry will benefit from using the hub-and-spoke approach. In a shipping hub, firms participate in upstream and downstream activities jointly and their collective economic actions lead to the emergence of a GSN. 
The proposed GSN concept in the PRD region can balance the interests of policy makers between reducing $\mathrm{CO}_{2}$ emissions and pursuing market-led port development. Lun (2011) used a case study to identify the key elements for successful green shipping management. Based on this initial study, three organizational antecedents as GSPs that are identified to the development of a GSN:

1. Cooperation with business partners: Sarkis (2003) develops a decision framework for evaluating alternatives of green practices adopted by firms that affect their external relationships with suppliers and customers. It is unlikely for shipping firms to adopt a GSN and change their ship routings when their partners in container operations are not actively involved in the network. Sheu et al. (2005) use a modelling approach to optimize the operations of forward and reverse logistics in a green supply chain. Their model and other similar studies emphasize cooperation with supply chain partners (Wong et al., 2009) and define a variety of characteristics and attributes. To successfully develop a GSN, cooperation between shippers and shipping lines is essential. With support from shippers to change the ports of call and sailing schedules, shipping lines may re-schedule their shipping routes to minimize their voyage distance and reduce the gross $\mathrm{CO}_{2}$ emissions. Furthermore, Zsidisin and Hendrick (1998) provide empirical evidence and identify several factors that influence green operations such as investment recovery (e.g., freight income from deploying ships), product design (e.g., ship routing), and supply chain relationships (e.g., support from shippers and other business partners). To perform shipping activities, shipping firms have established linkages with other users of the ports (Lun, 2008; Lun et al., 2009). These linkages with upstream and downstream firms in the region can be a factor affecting firms to improve environmental performance (Yang et al., 2009; Lun, 2010) by engaging in a GSN.

2. Environmentally friendly operations: Several models of environmentally friendly operations have been developed from the operational perspective. Handfield, et al. (2002) develop a decision model to measure environmental practice by using the multiple attribute utility theory approach. Kainumaa and Tawarab (2006) also use multiple attribute utility theory to assess supply chain performance throughout the life-cycles of materials, facilities, and services. Using life-cycle assessment, Faruk et al. (2002) advance knowledge on adoption of environmentally friendly operations by identifying materials acquisition, pre-production, production, distribution, and disposal as key measures. To assess the adoption of a GSN, it is essential to identify barge operators and feeder terminals, integrate operating system with feeder ports, use green shipping routes that emit less $\mathrm{CO}_{2}$, and develop a GSN to integrate shipping operations. On the other hand, ship operators may (1) source cleaner fuels at the materials acquisition stage, (2) re-think propeller design at the pre-production stage, (3) optimize ship engine during the voyage, (4) use waste heat recovery systems to reduce fuel consumption, and (5) use ballast water treatment systems to reduce the disposal of undesired organisms into the marine ecosystem. Walton et al. (1998) identify several dimensions to enhance environmental purchasing. From the perspective of GSPs, examples of environmental purchasing include the materials used in facility and equipment design to ensure a high recycling ratio at the time of scrapping barges and the decision processes that shippers use to select shipping services with routes that emit the lowest $\mathrm{CO}_{2}$ emissions.
Rationalization of liner shipping services to develop a GSN can also be seen as a tool to practice environmentally friendly operations.

3. Internal management support: There are a number of studies examining the relationship between green operations and internal management support. Carter et al. (1998) conduct an empirical study to examine green business operations. Their study identifies six key factors related to green business operations including top management support, middle management support, firm's mission, department goals, training for personnel to purchase environmentally friendly input, and evaluation of purchasing management. These findings imply that management support and company goals are factors affecting the adoption of a GSN. In addition, Zhu and Sarkis (2004) identify commitment from senior managers, support from mid-level managers, and cross-functional cooperation from environmental improvements as factors affecting internal environmental management. In short, previous studies (Shrivastava, 1995; Guimaraces and Liska, 1995) suggest that a number of benefits can be achieved by integrating environmental issues with corporate strategy. Hence, support by management team is one of the key elements to influence the adoption of a GSN. For instance, a leading global container terminal operator is committed to GSPs. The management team clearly defines its environmental policy as follows: (1) Legal Compliance, i.e., to comply with environmental regulations and set guidelines to achieve good environmental performance, (2) Pollution Protection and Waste Minimization, i.e., to incorporate environmental concerns in planning operational decisions to prevent pollution and reduce energy consumption, (3) Continual Monitoring and Improvement, i.e., to conduct periodic internal and external audits to monitor the environmental performance, and (4) Sustainable Development, i.e., communicate environmental objectives throughout the firm and its business partners in pursuit of green management practices. The resources commitment by top management is crucial to the implementation of environmental initiatives such as developing a GSN.

\section{DISCUSSIONS}

Shipping firms actively engaged in GSPs are more likely to outperform their competitors that are less supportive of a GSN. Environmental protection activities are embedded in business operations, where improving business operations efficiency to develop a GSN may bring benefits to firms. Thus, improvement in performance (e.g., shorten voyage distance to reduce waste of shipping capacity and related operating cost) may be one of the drivers for firms to implement a GSN. The subject of performance has received increasing interest from both academics and policy makers (Panayides and Lun, 2009). Potential benefits gained through pursuing GSPs include decreased fuel cost, waste treatment, and waste discharge. Benefits may also be generated by using larger ships to carry containers to and from PRD ports. a proactive pursuit of GSPs can prepare an enterprise for superior performance through reducing environmental risk and the development of capabilities for continuous environmental improvement. a number of findings support the view that GSPs are positively related to firm performance (Alvarez et al., 2001; Klassen and McClaghlin, 1996; Judge and Douglas, 1998). For instance, Rosso and Fouts (1997) link environmental performance to economic performance based on the resource-based view of the firm. They suggest that improved environmental performance 
will result in competitive advantage that is reflected by economic benefits. There are two categories of mechanisms for explaining the linkage between environmental and economic performance (Montabon et al., 2007). The first is "market gains", which include experience-based scale economies and higher margins. With the development of a GSN, the overall container throughput in the PRD region can be increased. This implies that terminal throughput and profit can be used as performance indicators in the container terminal industry. The second is "cost savings" such as greater productivity or lower operating cost due to reduced energy and materials consumption. For instance, a vessel of 12,000 TEU on the Europe-Far East route would generate an $11 \%$ cost saving per container slot compared to an 8,000 TEU vessel and a 23\% cost saving compared with a 4,000 TEU ship (Notteboom, 2004). Hence, lowering of the operating costs of shipping lines by using bigger ships in a GSN can be used as another performance indicator for liner shipping operations.

Although GSPs are essential to implementing a GSN, their levels of engagement vary among firms. GSPs involve a set of business processes that require firms to assess their environmental impacts, determine environmental goals, implement environmental operations, monitor goals attainment, and undergo management review. GSPs assist firms in scrutinizing their internal operations, engaging employees in environmental issues, continually monitoring for environmental improvement, and increasing their knowledge about their operations. These actions facilitate the improvement of firms' internal operations and create opportunities to gain competitive advantage. GSPs also encourage firms to use more sophisticated environmental strategies that build on their basic environmental protection principles to eliminate environmentally hazardous operating processes and redesign existing operating systems. Developing a GSN through engaging in GSPs offers an excellent opportunity for firms to assess all aspects of their operations jointly to minimize the shift of environmental harms from one subsystem to another and achieve greater organizational efficiency. GSPs focus on identifying best practices that simultaneously reduce the negative impacts of firms' activities on the natural environment and contribute to better firm performance. Unlike regulatory requirements that are derived from the outside, GSPs consist of operational processes that arise from within a firm. GSPs are a collection of internal efforts in business planning and implementation. GSPs consist of a business policy and a set of business processes that require firms to assess their environmental impacts, determine environmental goals, implement environmental operations, monitor goals attainment, and undergo management review. Through continual environmental and organizational improvement, firms may enjoy opportunities to enhance their performance.

\section{CONCLUSIONS}

Global economic development is supported by the commercial shipping industry. Shipping operations by maritime transport contributes to the growth of international trade activities, which heavily depends on ships to transport cargoes from places of production to places of consumption. Carriage by sea has increased by $50 \%$ in the past two decades and accounts for approximately $90 \%$ of the global trade volume. The movement of containerships emits $\mathrm{CO}_{2}$ from fuel consumption during the voyage. Depending on ship size, ocean-going vessels emit between 15 and 21 grams of $\mathrm{CO}_{2}$ per ton-km (International Chamber of Shipping, 2010), leading to concerns about the environmental damage caused by shipping activities. There are studies exploring the use of cleaner fuels and the development of emission control areas. Nevertheless, the fees charged for accessing emission control areas and the capital investment for adopting cleaner fuels will add costs to shipping operations, which lifts freight rates. Consequently, traders may bear higher freight rates for shipping cargoes between ports with emission control. Such development can be detrimental to the competitiveness of such ports as high freight rates discourage trade activities and consequently dampen shipping demand.

Hong Kong and Shenzhen are two of the top five global container ports servicing the same hinterland in the Pearl River Delta (PRD) region. Since the two cities are closely linked geographically and economically, port operations should be coordinated with strategic port policies. However, counterproductive competition exists between the two ports due to their unclear roles and a lack of shipping network development in the PRD region. This study contributes to port policy development in the PRD region by classifying ports in the region as feeder ports and hub ports. Such classification will provide policy insights for developing a green shipping network (GSN) that will emit lower $\mathrm{CO}_{2}$ in the region. Feeder ports refer to ports that emit a higher level of $\mathrm{CO}_{2}$ when they act as ports of loading for containerships. The total emissions can be substantially reduced if barges are used to transport containers to hub ports in the PRD region. Developing a GSN based on the port classification to be developed in this study will yield the following advantages: (1) selection of shipping routes by shipping firms that produce less air pollution, thus reducing the global warming effect, (2) reduction of double or triple calling of ports in the PRD region, so reducing $\mathrm{CO}_{2}$ emissions, and (3) development of green shipping hubs (GSHs) in the PRD region, hence strengthening the competitiveness of the region. This timely study will provide insights for policy makers to "green" the pillar shipping industry, which services the vast manufacturing base in the PRD region, yielding enhanced productivity and efficiency.

\section{Appendix 1: Formulas to determine the voyage distances of a direct voyage and alternative routes} between the ports in the PRD region and their discharging ports

The environmental cost for container transport from a port of loading $\mathrm{r}$ to a port of discharge $\mathrm{s}$ can be written as:

$$
\mathrm{EC}_{\mathrm{rs}}=\sum_{\mathrm{i}} \mathrm{ec}_{1} \mathrm{~d}_{\mathrm{rs}, \mathrm{i}} \mathrm{s}_{\mathrm{rs}, \mathrm{i}}
$$

where $\mathrm{ec}_{1}$ is the environmental cost for transport mode 1 , which is defined in this study as containership transport. $d_{r s, i}$ and $s_{r s, i}$ are the demand and equivalent containership travel distance from the port of loading $r$ to the port of discharge $s$ through route i, respectively. Note that

$$
\mathrm{S}_{\mathrm{rs}, \mathrm{i}}=\sum_{\mathrm{m}}\left(\mathrm{ec}_{\mathrm{m}} / \mathrm{ec}_{1}\right) \mathrm{s}_{\mathrm{rs}, \mathrm{i}}^{\mathrm{m}}
$$


where $\mathrm{s}_{\mathrm{rs}, \mathrm{i}}^{\mathrm{m}}$ represents the total distance travelled using mode $\mathrm{m}$ transport along route $\mathrm{i}$ from the port of loading $\mathrm{r}$ to the port of discharge $\mathrm{s}$.

In order to minimize the environmental cost, all the demands between a particular port of loading $\mathrm{r}$ and a port of discharge $\mathrm{s}$ must use the shortest route. Therefore,

$$
\min _{\mathrm{EC}}=\min _{\mathrm{i}} \sum_{\mathrm{i}} \mathrm{ec}_{1} \mathrm{~d}_{\mathrm{rs}, \mathrm{i}} \mathrm{s}_{\mathrm{rs}, \mathrm{i}}=\mathrm{ec}_{1} \mathrm{~d}_{\mathrm{rs}} \operatorname{mins}_{\mathrm{i} \mathrm{rs}, \mathrm{i}}
$$

Thus, once the equivalent containership travel distances have been calculated for all the possible routes from $r$ to $s$, the minimum environmental cost for transporting containers from $r$ to $\mathrm{s}$ can be determined using the shortest route.

The next step is to convert barge distance to an equivalent containership distance (ECD) by multiplying the barge distance with the ratio of the environmental cost for barge transport to that for containership transport. Therefore,

$$
1 \text { barge distance }=(3.3 / 6.3)=0.53 \mathrm{ECD}
$$

With the barge distances between the origin ports and the containership distances between origins and destinations, the ECD travelled on all the routes can be determined as:

$0.53 \times$ barge distance between ports in the PRD region + containership distance from port of loading to port of discharge

\section{REFERENCES}

1. Alvarez G., Jimenez J.B. and Lorente J.C., 2001, An analysis of environmental management, organizational context and performance of Spanish hotels, Omega, 29(6): 457-471

2. Asteris M. and Collins A., 2007, Developing Britain's port infrastructure: markets, policy, and location, Environment and Planning A, 39: 2271-2286

3. Bergstrom J. and Taylor L.O., 2006, Using meta-analysis for benefits transfer: Theory and practice, Ecological Economics, 60(2): 351-360

4. Boyle K., Kuminoff N.V., Parmeter C.F. and Pope J.C., 2008, Necessary conditions for valid benefit transfer, American Journal of Agricultural Economics, 91(5): 1328-1334

5. Carter C.R., Ellram L.M. and Kathryn, L.M., 1998, Environmental purchasing: Benchmarking our German counterparts, International Journal of Purchasing and Material Management, 34(4): 28-38

6. Eisenhardt, K.M., 1989, Building theories from case study research. Academy of Management Review, 14(4): p. 532-550.

7. Faruk A.C., Lamming R.C., Cousing P.D. and Bowen F.E., 2002, Analyzing, mapping, and managing environmental impacts along the supply chain. Journal of Industrial Ecology, 5(2): 1336

8. Gallagher K.P., 2009, Economic globalization and the environment, Annual Review of Environment and Resources, 34: 279-304

9. Glaser, B. and A. Strauss, 1967, The Discovery of Grounded Theory: Strategies for Qualitative Research, Chicago: Aldine

10.Guimaraes T. and Liska K., 1995, Exploring the business benefits of environmental stewardship, Business Strategy and the Environment, 4(1): 9-22

11.Handfiled R., Walton S. and Sroufe R., 2002, Applying environmental criteria to supplier assessment: a study of the application of the analytical hierarchy process, European Journal of Operational Research, 141: 70-87

12.International Chamber of Shipping, 2010, Shipping, World Trade and the Reduction of $\mathrm{CO}_{2}$ Emissions, published by International Maritime Organization (IMO) Marine Environment Protection Committee

13.Judge W.Q. and Douglas T.J., 1998, Performance implications of incorporating natural environmental issue into the strategic planning process: an empirical assessment, Journal of Management Studies, 35(2): 241-262

14.Kainumaa Y. and Tawarab N., 2006, a multiple attribute utility theory approach to learn and green supply chain management, International Journal of Production Economics, 101(1): 99-108
15.Lai K.H., Lun Y.H.V., Wong C.W.Y. and Cheng T.C.E., 2011, Green practices in the shipping industry: Conceptualization, adoption, and implications, Resources, Conservation and Recycling, 55(6): 631-638

16.Lun Y.H.V., Pang K.W. and Panayides P.M., 2010, Organizational growth and firm performance in the international container shipping industry, International Journal of Shipping and Transport Logistics, 2(2): 203-226

17.Lun Y.H.V. and Cariou P., 2009, An analytical framework for managing container terminals, International Journal of Shipping and Transport Logistics, 1(4): 419-436

18.Lun Y.H.V. and Browne M., 2009, Fleet mix in container shipping operations, International Journal of Shipping and Transport Logistics, 1(2): 103-118

19.Lun Y.H.V., 2011, Green management practices and firm performance: a case of container terminal operations, Resources, Conservation and Recycling, 55(6): 559-566

20.Lun Y.H.V., Lai K.H. and Cheng T.C.E. (2011), Investigation of the influences of transport complex economy and political risk on freight transport growth, International Journal of Logistics: Research and Application, 14(5): 285-296

21.Lun Y.H.V. and Marlow P.B. (2011), The impact of capacity on firm performance: a study of the liner shipping operations, International Journal of Shipping and Transport Logistics, 3(1): $57-71$

22.Lun Y.H.V., Lai K.H. and Cheng T.C.E., 2010, Shipping and Logistics Management. Springer: London, UK

23.Lun Y.H.V., Lai K.H. and Cheng T.C.E., 2009, a descriptive framework for the development and operation of liner shipping network, Transport Reviews, 29(4): 439-457

24.Lun Y.H.V., 2008, Adoption of Electronic Commerce by Logistics Service Providers in Hong Kong, VDM: Saarbrucken, Germany

25.Metz B., Davidson O.R., Bosch P.R., Dave R., Meyer L.A 2007. Contribution of Working Group III to the Fourth Assessment Report of the Intergovernmental Panel on Climate Change. Cambridge University Press: Cambridge (USA) and New York (USA).

26.Miles, M.B. and Huberman, A.M., 1994, An Expanded Sourcebook Qualitative Data Analysis, Thousand Oaks, California: Sage Publications, Inc.

27.Montabon F., Sroufe R. and Narasimhan, 2007, An examination of corporate reporting, environmental management practices and firm performance, Journal of Operations Management, 25: 998-1014

28.Notteboom T., 2004, Container shipping and ports: an overview. Reviews of Network Economics, 32(2), 86-106 
29.Panayides P.M. and Lun Y.H.V., 2009, The impact of trust on innovativeness and supply chain performance, International Journal of Production Economics, 122(1): 35-46

30.Rosso M.V. and Fouts P.A., 1997, a resource based perspective on corporate environmental performance and profitability, Academy of Management Journal, 40(3): 354-559

31.Sarkis J., 2003, a strategic decision marking framework for green supply chain management, Journal of Clear Production, 11(4): 397-409

32.Sarkis, J., Zhu, Q., and Lai, K.H., 2010, An organizational theoretic review of green supply chain management, International Journal of Production Economics, 130(1): 1-15

33. Sheu J.B., Chou Y.H. and Hu J.J., 2005, An integrated logistics operational model for green supply chain management, Transportation Research: Part E, 41(4): 287-313

34. Shrivastava P., 1995, Environmental technologies and competitive advantage, Strategic Management Journal, 6: 183200

35.Walton S.Y., Handfield R.B. and Melnky S.T., 1998, The green supply chain: Integrating suppliers into environmental management process, International Journal of Purchasing and Materials Management, Spring, 2-11

36.Wong C.W.Y., Lai K.H. and Ngai E.W.T., 2009, The role of supplier operational adaptation on the performance of ITenabled logistics under environmental uncertainty, International Journal of Production Economics, 122 (1), 47-55

37.Yang J., Wong C.W.Y., Lai K.H. and Ntoko A.N., 2009, The antecedents of dyadic quality performance and its effect on buyer-supplier relationship improvement, International Journal of Production Economics, 120 (1), 243-251
38. Yin, R.K., 2003, Case Study Research: Design and Methods, Thousand Oaks, C.A.: Sage Publications

39.Zhang F., Ng C.T., Tang G., Cheng T.C.E. and Lun Y,H.V., 2011, Inverse Schedule: Application shipping, International Journal of Shipping and Transport Logistics, 3(3): 312-322

40.Zhu Q.H. and Sarkis J., 2004, Relationships between operational practices and performance among early adopters of green supply chain management practices in Chinese manufacturing enterprise, Journal of Management, 22: 265-289

41.Zsidisin G.A. and Hendrick T.C., 1998, Purchasing's involvement in environmental issues: a multi-country perspective, Industrial Management and Data Systems, 7: 313320

\section{Acknowledgement}

This study was supported in part by The Hong Kong Polytechnic University under the grant number A-PK33

\section{CONTACT WITH THE AUTHOR}

Y.H. Venus Lun, DBA, Assistant Professor Shipping Research Centre

The Hong Kong Polytechnic University

1, Yuk Choi Road, Hung Hom, Kowloon, HONG KONG email: lgtvlun@polyu.edu.hk 